\title{
A non-lethal method to estimate CYP1A expression in laboratory and wild Atlantic salmon (Salmo salar)
}

\author{
Christopher B. Rees ${ }^{\text {a }}$, Stephen D. McCormick ${ }^{\mathrm{b}}$, Weiming Li ${ }^{\mathrm{a}, *}$ \\ ${ }^{a}$ Department of Fisheries and Wildlife, 13 Natural Resources Building, Michigan State University, East Lansing, MI 48824, USA \\ ${ }^{\mathrm{b}}$ Conte Anadromous Fish Research Center, USGS, Biological Resources Division, P.O. Box 796, Turners Falls, MA 01376, USA
}

Received 22 December 2004; received in revised form 14 April 2005; accepted 18 April 2005

Available online 27 July 2005

\begin{abstract}
Expression of cytochrome P4501A (CYP1A) has been used as a biomarker for possible exposure to contaminants such as PCBs and dioxins in teleost fish. Using a quantitative reverse transcription-polymerase chain reaction (Q-RT-PCR) and a non-lethal gill biopsy, we estimated levels of CYP1A mRNA expression in Atlantic salmon (Salmo salar). Groups of ten Atlantic salmon juveniles (48-76 g) received an intraperitoneal injection of $50 \mu \mathrm{g} \mathrm{g}^{-1} \beta$-naphthoflavone (BNF) or vehicle. Their gill tissues were repeatedly sampled by non-lethal biopsies on day 0,1,2 and 7. Control fish expressed basal levels of CYP1A over the duration of sampling. BNF-treated salmon demonstrated similar levels of CYP1A to control fish at day 0 and higher levels over the course of each additional sampling point. Gill biopsies from wild salmon sampled from Millers River (South Royalston, Worcester County, MA, USA), known to contain PCBs, showed significantly higher CYP1A levels over an uncontaminated reference stream, Fourmile Brook (Northfield, Franklin County, MA, USA). We conclude that gill biopsies coupled with Q-RT-PCR analysis is a valuable tool in environmental assessment of wild Atlantic salmon populations and has the potential to be applied to other populations of fish as well.
\end{abstract}

(C) 2005 Elsevier Inc. All rights reserved.

Keywords: Atlantic salmon; CYP1A; Gill biopsies; Quantitative PCR; Salmo salar; PCBs; Biomarkers; Environmental assessment

\section{Introduction}

For endangered fish species, it has become increasingly important to assess the health and stress levels in remaining wild stocks. However, direct assessment through conventional lethal sampling procedures is difficult, if not impossible, to justify. For instance, the wild Atlantic salmon (Salmo salar), once an abundant and prized sport fish, is in danger of becoming extinct from the United States and some areas of Northeastern Canada. Habitat destruction, over fishing, damming of rivers (MacCrimmon and Gots, 1979), disease (Bakke and Harris, 1998), competition from hatchery-stocked salmon (Youngson and Verspoor, 1998), and contaminants (Elson, 1967; Fairchild et al., 1999) have contributed to Atlantic salmon declines, especially in the

\footnotetext{
* Corresponding author. Tel.: +1 517353 9837; fax: +1 5174321699 .

E-mail address: liweim@msu.edu (W. Li).
}

southern reaches of their native range (Parrish et al., 1998). This has resulted in the listing of Atlantic salmon on the US Endangered Species List as of November 2000 in the state of Maine (U.S. Department of Interior, 2000). They are also considered endangered in the Inner Bay of Fundy in New Brunswick and Nova Scotia of Eastern Canada (Committee on the Status of Endangered Wildlife in Canada, 2002). To conserve this species, extensive physiological and toxicological studies are needed to confirm or eliminate potential causes for the decline of wild Atlantic salmon.

Traditionally, determination of contaminant body burdens or organismal response to toxicant exposure usually requires destructive (lethal) sampling. As a result, direct assessment of this response in endangered wild stocks, which would directly implicate their current physiological conditions and potential stress by environmental factors, is rare. In fish, the effects of pesticides and organic contaminants are typically sub-lethal and occur at the molecular level. Because of the advent of innovative and sensitive 
techniques to measure the molecular effects of contaminant exposure, from a conservation standpoint, it would be helpful to develop assays that do not require sacrificial sampling of fish to measure necessary endpoints.

A series of investigations have been carried out recently focusing on the sub-lethal mechanisms associated with contaminant exposure and reproductive impairment in fish populations (Jones et al., 1998; Moore and Waring, 2000; topic in review McMaster, 2001). Some have used correlational studies to link the regional dwindling of salmon stocks to historical application of pesticides in those same areas (Fairchild et al., 1999). Likewise, it is fairly well documented that atrazine and nonylphenol have physiological effects on salmonid species (Moore and Waring, 1998; Moore et al., 2003). However, these compounds are not known to induce the cytochrome P4501A family of monooxygenase enzymes.

CYP1As constitute the genes that encode for cytochrome P4501A enzymes. CYP1A induction, or the increased expression and abundance of CYP1A mRNA, is a well-documented phenomenon in teleost fish (OrtizDelgado and Sarasquete, 2004; Billiard et al., 2004; Jonsson et al., 2004) and occurs when planar halogenated compounds (PAHs, PCBs, TCDD, etc.) bind to a cytosolic ligand-activated transcription factor known as the Ah (aryl hydrocarbon) receptor (Sarasquete and Segner, 2000; Hahn and Stegeman, 1994). This specific binding ultimately results in upregulation of the CYP1A gene through the activation of the Ah-receptor response elements in the promoter region of the CYP1A gene. Although CYP1As are not induced specifically by pesticides, some researchers have found links between the estrogenic effects of pesticides on vitellogenesis, oocyte maturation, and zonagenesis and the inducing effects of aryl hydrocarbon receptor agonists (Arukwe et al., 2001; Navas and Segner, 2001). These studies suggest that there are molecular relationships and cross-talk between the Ah-receptor and estrogen signalling pathways. It is possible that intermediate compounds that act through either or both pathways may have reproductive consequences. The effects of this cross-talk could be detrimental for an endangered population, therefore it is important for researchers and managers to understand relationships between the Ahreceptor and estrogen pathways.

In this study, we attempted to develop a non-lethal method to assess levels of gene expression rapidly and accurately. Expression of particular genes is often associated with specific physiological function or response to environmental changes and is a good indicator for exposure to a variety of environmental stimuli. Our primary objective was to illustrate a concept that can be adapted to study the expression of virtually any gene of fish in tissues suitable for biopsies. Specifically, we selected CYP1A of Atlantic salmon as our model system to develop this approach for several reasons. First, CYP1A induction has been used as a biochemical marker of exposure to aryl hydrocarbon receptor agonists such as PCBs, PAHs, and dioxins. Therefore, such an assay could be used directly to study responses to a variety of toxicants in fish. More importantly, we have established a quantitative reverse transcriptionpolymerase chain reaction (Q-RT-PCR) assay and used it to measure levels of CYP1A mRNA in Atlantic salmon tissues induced by xenobiotics (Rees et al., 2003). This is important because one of our primary objectives is to compare the anticipated data from the new gill biopsy methods directly to the previous set of data on CYP1A expression collected from tissues through destructive sampling (Rees et al., 2003). Such a comparison provides further evaluation of the reliability of a gill biopsy for estimating levels of CYP1A gene expression. In addition, there are a number of other QRT-PCR assays that have been developed to measure CYP1A mRNA expression in fish (Campbell and Devlin, 1996; Miller et al., 1999; Cousinou et al., 2000) that provide good models for data comparison. Here we describe development of this new approach, report the first timecourse of CYP1A induction established in a single group of fish, and show utility of this new method in assessing gene expression of fish from the wild.

\section{Materials and methods}

\subsection{Gill biopsies}

Non-lethal gill biopsies were collected according to McCormick (1993). Briefly, Atlantic salmon (S. salar L.) were anaesthetised by immersion in buffered $100 \mathrm{mg} \mathrm{L}^{-1}$ MS-222 (pH7.0). The distal half of six gill filaments were excised from the first gill arch (refer to Fig. 1 for a picture of the area of sampling), stored immediately in $300 \mu \mathrm{L}$ of RNALater $^{\circ}$ (Ambion; Austin, TX, USA), and packed on dry ice. Samples were stored at $-80^{\circ} \mathrm{C}$ for further analysis.

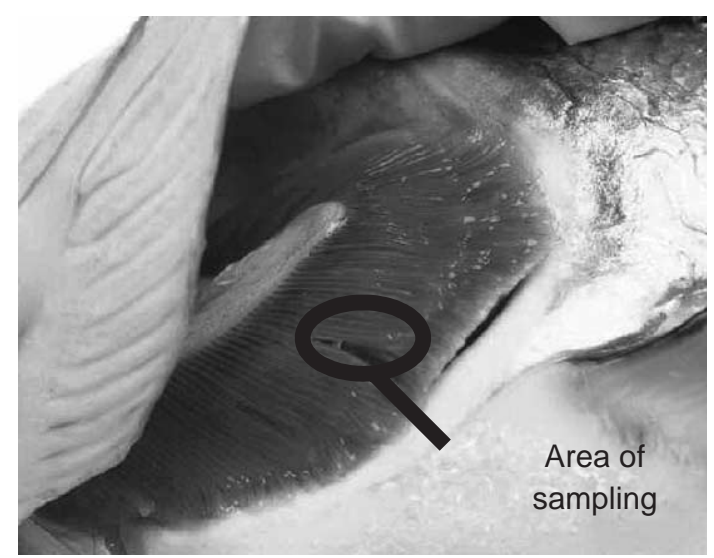

Fig. 1. The location of sampling for gill biopsies. All biopsies were taken from centrally located filaments only from the distal end. For non-lethal sampling, 5-7 filaments $(<0.5 \mathrm{~cm}$ in length) are adequate for Q-RT-PCR analysis. 


\subsection{Total RNA extractions}

For quantitative PCR analysis, it is essential that the extracted RNA samples be highly pure with no genomic DNA. To achieve the desired results, we used a RNA filtration-based technique (Absolutely RNA ${ }^{\mathrm{TM}}$ Nanoprep Kit; Stratagene; La Jolla, CA, USA). Total RNA was resuspended in $10 \mu \mathrm{L}$ of diethylpyrocarbonate-treated water (DEPC $-\mathrm{H}_{2} \mathrm{O}$ ) and quantified (Sambrook et al., 1989) spectrophotometrically.

\subsection{RNA quality}

Quality of RNA was verified by the use of a spectrophotometer and by analysing samples on an agarose gel. Subsets of extracted RNA samples were size-fractionated on a $1 \%$ agarose gel containing $0.1 \mu \mathrm{g} \mathrm{mL}-1$ ethidium bromide (Sambrook et al., 1989) and analysed for genomic DNA contamination (example of gel in Fig. 2). Based on spectrophotometer and agarose gel analysis, we determined that RNA samples with an A260/A280 ratio of $\geq 1.0$ or an A230 of $<0.1500$ were considered adequate for the Q-RTPCR assay. Samples not meeting these criteria $(10 \%$ of the total) were discarded from the statistical analysis.

\subsection{Time-course induction study}

Atlantic salmon juveniles (15-19 cm, 48-76 g) were held at the Conti Anadromous Fish Research Center in Turners Falls, MA, USA in 1-m diameter tanks with flowthrough Connecticut River water $\left(4 \mathrm{~L} \mathrm{~min}^{-1}\right)$ maintained at $10-11{ }^{\circ} \mathrm{C}$ under natural daylight conditions. These salmon were hatched and raised in a culture setting, not collected from the wild. Salmon were fed by hand to satiation twice per day (Ziegler's; Gardners, PA, USA). Salmon were taken off of feed two days prior to injection. Gill biopsies were collected from each individual immediately before injection

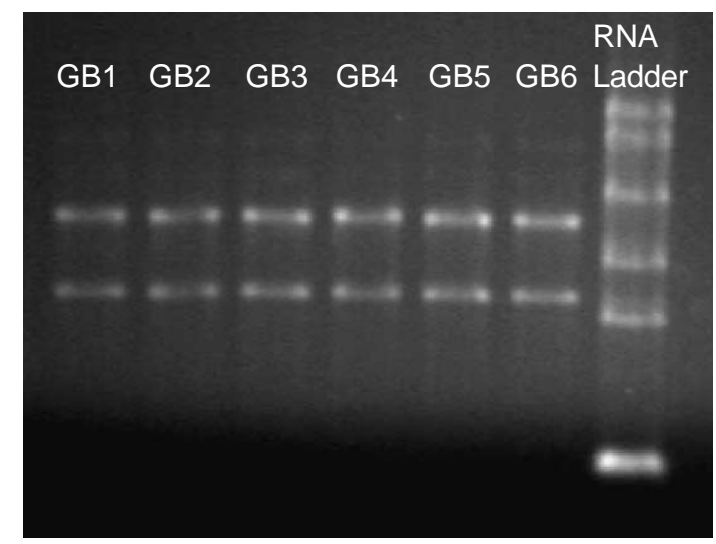

Fig. 2. Agarose gel ( $1 \%$ gel stained with $0.1 \mathrm{ug} \mathrm{ml}^{-1}$ ethidium bromide) analysis of gill biopsy total RNA using the Stratagene Nanoprep Kit. In each well, $150 \mathrm{ng}$ of total RNA was loaded representing individual extractions. Lane 7 includes a $0.24-9.5$ kb RNA ladder (Life Technologies; Rockville, MD). and stored in RNALater. After biopsies were taken at time 0, one group of salmon was given an intraperitoneal injection of corn oil only $(n=10)$ while the other group $(n=10)$ received an injection of corn oil with $\beta$-naphthoflavone (BNF, $50 \mu \mathrm{g} \mathrm{g}^{-1}$ ), a known inducer of the CYP1A gene in Atlantic salmon (Rees et al., 2003). After injections, nonlethal gill biopsies were taken at 1, 2, and 7 days. Salmon were sacrificed on the 7 th day of the experiment by an overdose of MS-222. At that time, liver was also sampled for use as a reference tissue.

\subsection{Salmon from the wild}

To show the utility of the Q-RT-PCR assay in fish gill biopsies from the wild, we sampled juvenile Atlantic salmon (9-68 g) by electro-shocking from two rivers in Massachusetts, Fourmile Brook and Millers River $(25.8 \mathrm{~km}$ apart from each other), on November 16th, $2001\left(6.3-7.3{ }^{\circ} \mathrm{C}\right)$. Millers River had been found in the past to contain contaminated waters, sediment, and fish with high levels of PCB contamination (Colman, 2001). Fourmile Brook was considered an 'uncontaminated reference stream'. Fish in these streams were planted as fry as part of the Connecticut River Restoration Program. Ten fish were collected from each site after which gill biopsies were immediately taken and stored in $300 \mu \mathrm{L}$ of RNALater. The juveniles were returned to the stream.

\subsection{Quantitative RT-PCR}

Construction of the internal standard has been described previously (Rees et al., 2003). Briefly, this assay consisted of a competitive RT-PCR where the target gene and internal standard were co-reverse transcribed and co-amplified in the same reaction vessel. In this reaction, both templates compete for the same primers, therefore the relative formation of IS or CYP1A PCR products is completely dependent upon the abundance of each template. Standard curves were generated for each tissue and treatment by coreverse transcription and co-amplification of a constant amount of total RNA (100ng) against a dilution series of internal standard $\left(10^{9}\right.$ molecules $-10^{4}$ molecules $)$. Synthesis of cDNA followed that of Rees et al. (2003). Two microliters of cDNA mixture were added to a $50 \mu \mathrm{L}$ PCR mix containing $3 \mathrm{mM} \mathrm{MgCl}_{2}, 2.5$ units Taq Polymerase, 30 pmol of each hex-labeled (Integrated DNA Technologies; Coralville, IA, USA) forward and reverse primer (WML51 5'-CTG TCT TGG GCC GTT GTG TAC CTT GTG-3' and WML52 5'-TAT CCT TGA TCG TGC AGT GTG GGA TGG- $3^{\prime}$ ), and $0.4 \mathrm{mM}$ dNTPs. The reaction mix was heated to $94{ }^{\circ} \mathrm{C}$ for $4 \mathrm{~min}$, followed by 30 cycles of a $94{ }^{\circ} \mathrm{C}$ denaturation for $20 \mathrm{~s}$, a $70{ }^{\circ} \mathrm{C}$ annealing step for $30 \mathrm{~s}$, and a $72{ }^{\circ} \mathrm{C}$ extension step for $30 \mathrm{~s}$. An additional $5 \mathrm{~min}$ extension step was included at the conclusion of the 30 cycle main reaction. The size of the internal standard and CYP1A PCR products were 321 and $208 \mathrm{bp}$, respectively. 
Because RT-PCR is extremely sensitive and the reaction setup requires the transfer of small volumes of liquid, it is important to carefully consider positive and negative controls. We implemented four during analysis. First, the internal standard controls for variability of reverse transcription and PCR amplification. Secondly, a blank IS RTPCR reaction acted as an additional size marker and, to verify the IS was amplified as a single product. Thirdly, densities were calibrated among gels by loading an absorbance standard (AS) in each gel, a 1:10 dilution of a previously amplified CYP1A PCR product. Finally, a negative (water-added) reverse transcription control was included to verify the absence contaminating DNA during reverse transcription.

PCR products were visualized on $4 \%$ non-denaturing polyacrylamide (BioRad; Hercules, CA, USA) gels at $20 \mathrm{~V}$ $\mathrm{cm}^{-1}$. Product size was determined using a hex-labeled MAPMARKER $^{\mathrm{TM}}$ molecular size standard (Bioventures Inc.; Murfreesboro, TN, USA). Densitometric readings were calculated using an FMBIO II Laser Scanner (Hitachi Genetic Systems; Alameda, CA, USA) and software (ReadImage version 1.5, Analysis v8.0). Use of standard curves and computation of target gene expression is described by Vanden Heuvel (1998).

\subsection{Statistical analysis}

All analyses were carried out using Statistical Analyses System (SAS Institute; Cary, NC, USA). Q-RT-PCR data was transformed logarithmically to satisfy normality and homogeneity of variance requirements. Time and treatment effects for the gill biopsy-lab induction study were analysed using a repeated measures mixed effect ANOVA (PROC MIXED). A Tukey-Kramer adjustment was used to determine differences between biopsy samples from experimental and control groups. Student $t$-tests were used to compare means between Millers River and Fourmile Brook CYP1A levels and also CYP1A levels in liver samples collected from untreated and BNFinjected salmon.

\section{Results}

\subsection{Time-course laboratory induction experiment}

BNF treatment significantly increased the levels of CYP1A mRNA in gills (ANOVA, $P<0.0001$; Fig. 3a). Gill biopsies from each group of salmon demonstrated no difference in CYP1A levels prior to injection (TukeyKramer, $P>0.10$ ). In contrast, after injection, gill biopsies from salmon injected with BNF showed a 12-fold induction of CYP1A mRNA over control salmon after 1 day (Tukey-Kramer, $P<0.0001$ ). Maximal induction of $85 \times$ over control levels occurred after 2 days and remained at 85-fold induction after a 7-day exposure
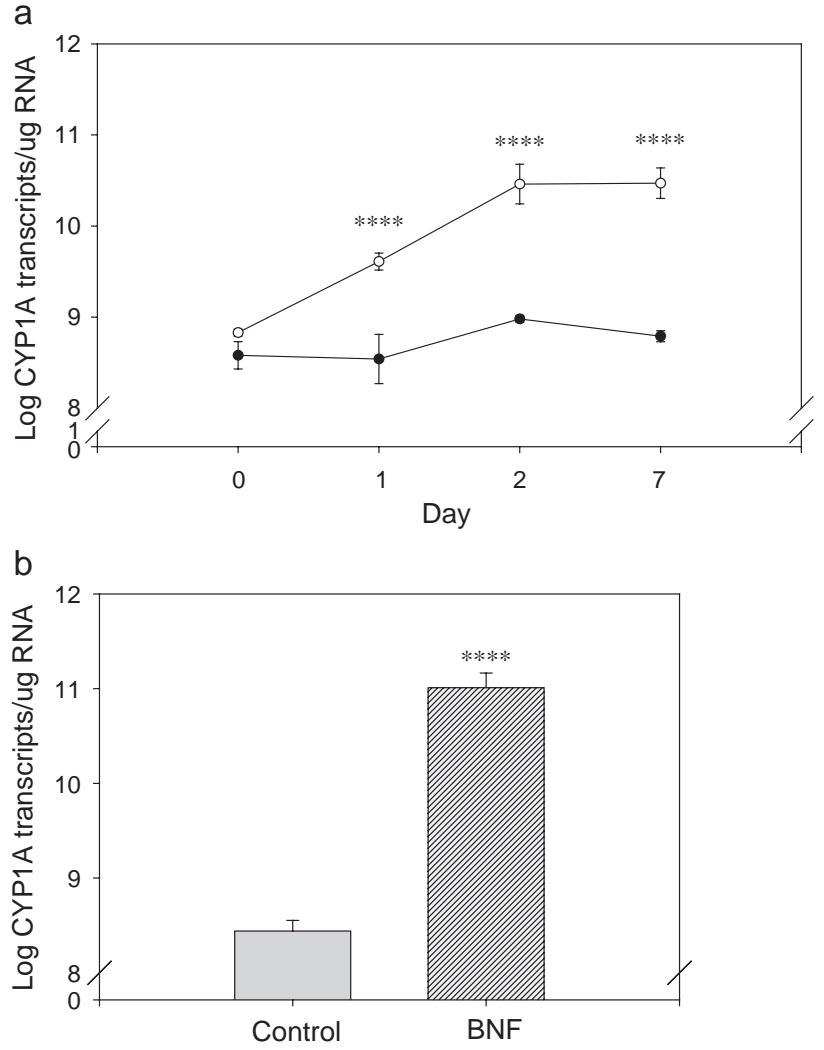

Fig. 3. a. Log mean number of CYP1A transcripts per microgram of total RNA over time. Gill biopsies were taken (non-lethally) from both control (O) and experimental (O) groups ( $n=10$ for each) immediately before intraperitoneal injection and 1, 2, and 7 days after injection. Asterisks indicate significance of difference (Tukey-Kramer, $P<0.0001$ ) between CYP1A mRNA levels from gill biopsies of BNF-injected $\left(50 \mathrm{mg} \mathrm{kg}^{-1}\right.$ $\mathrm{BNF}$ ) and corn oil-injected salmon for each day, respectively. The vertical bars indicate the standard error of the mean (SEM). b. Log mean number of CYP1A transcripts per microgram of total RNA in liver tissue of Atlantic salmon 7 days post-injection. The liver samples came from the same animals used for taking gill biopsies during $0,1,2$, and 7 days in the timecourse experiment. Asterisks indicate significance of difference (Students $t$ test, $P<0.0001$ ) between CYP1A mRNA levels from liver tissue of BNFinjected and corn oil-injected salmon. The vertical bars indicate the standard error of the mean (SEM).

(Tukey-Kramer, $P<0.0001$ ). CYP1A mRNA in liver tissue after 7 days of exposure was induced 370 -fold in salmon treated with BNF compared to control salmon (Student $t$-test, $P<0.0001$; Fig. $3 b$ ).

\subsection{Gill biopsies from salmon in the wild}

Gill CYP1A mRNA levels in Atlantic salmon from the Millers River were 66-fold induced compared to salmon from Fourmile Brook (Student $t$-test, $P<0.0001$; Fig. 4). In addition, levels of gill CYP1A mRNA in control fish of the lab induction study were 2-fold higher than salmon sampled from Fourmile Brook. Likewise, Atlantic salmon from Millers River expressed CYP1A mRNA in gill tissue at $1.62 \times$ the levels found in BNF-induced salmon in the lab. In both cases, CYP1A expression estimates were similar 
a

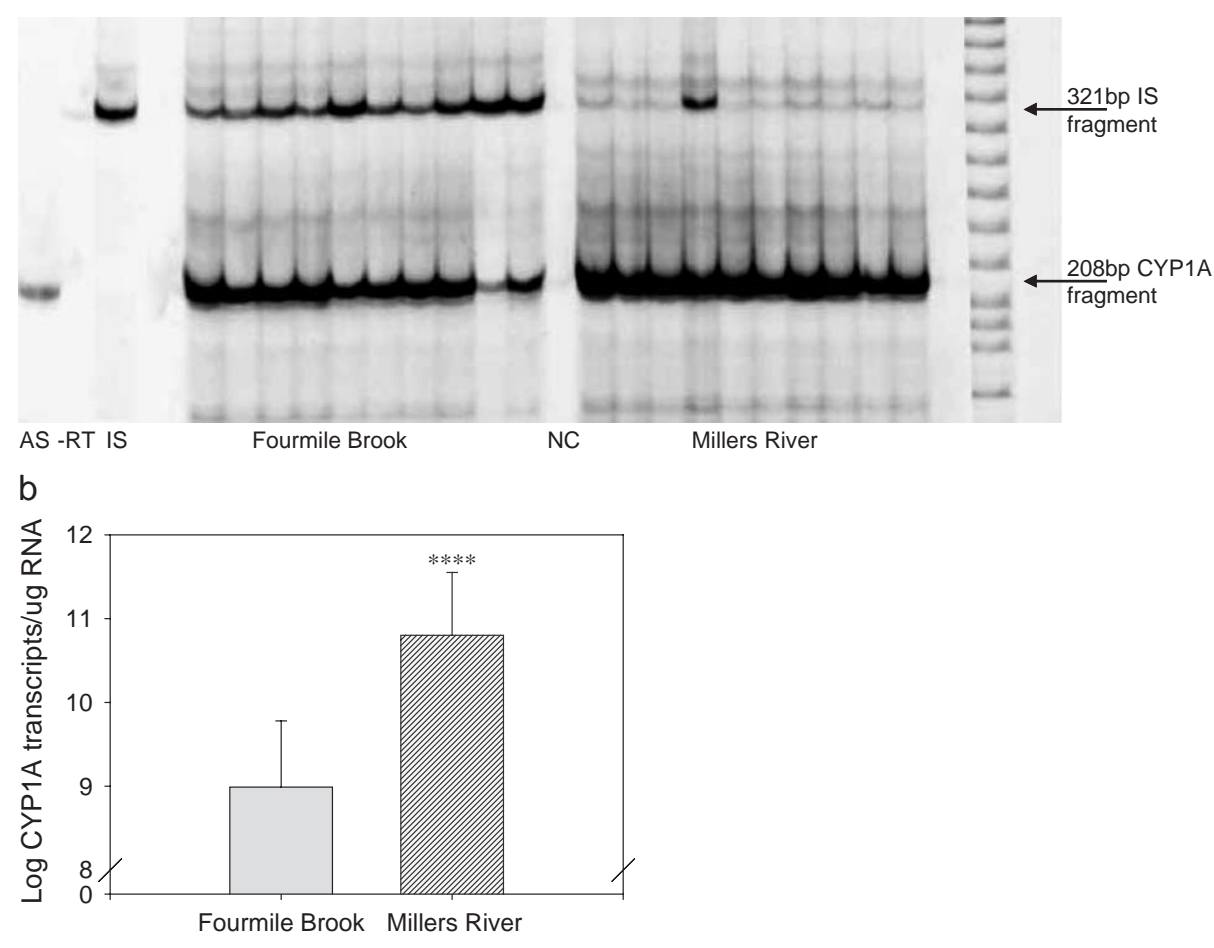

Fig. 4. a. Representative gel pictures for gill biopsies taken from wild Atlantic salmon of Millers River and Fourmile Brook. RNA (100 ng) was co-transcribed and co-amplified with a RNA internal standard of a known concentration (IS). Each lane represents one individual $(n=10)$. The bands near the top of each gel are the $321 \mathrm{bp}$ IS. The bands at the bottom of each gel represent the $208 \mathrm{bp}$ CYP1A fragment. PCR fragment size was determined by comparison to a hexlabeled MAPMARKER ${ }^{\mathrm{TM}}$ molecular size standard as seen on the right side of the gel (Bioventures Inc.; Murfreesboro, TN, USA). CYP1A mRNA levels are determined by taking the density ratio of IS/CYP1A and comparing to a standard curve. NC, negative control (water control); - RT, negative reverse transcription control (water control); AS, absorbance standard for calibration of densities between gels; and IS, internal standard positive control. b. Log mean number of CYP1A transcripts per microgram of total RNA from gill biopsies of wild Atlantic salmon from two Massachusetts streams, Millers River (PCB contaminated) and Fourmile Brook (uncontaminated reference stream). Asterisks indicate significance of difference (Student's $t$-test, $P<0.0001)$ between CYP1A levels from gill biopsies of salmon sampled from Fourmile Brook and Millers River. Vertical bars indicate the standard error of the mean (SEM).

between fish captured in a natural stream and laboratoryraised fish.

\section{Discussion}

Using non-lethal gill biopsies from Atlantic salmon we have shown that CYP1A mRNA is highly inducible and that the results are consistent with those collected from destructive sampling. In particular, after 1 day of exposure induced salmon demonstrated a 12-fold induction of CYP1A mRNA over control levels. The trend of induction continued after 2 days of exposure where BNF-induced salmon showed an 85-fold induction of CYP1A over control individuals. Maximal induction was reached at this point in the gill samples. This level of induction was maintained over the remainder of the 7-day time-course experiment. These results are consistent with previous findings. In Atlantic salmon liver tissue, previous research has demonstrated using Northern blotting techniques that CYP1A mRNA maximal induction is reached after 2 days (Grosvik et al., 1997). In addition, ELISA analysis of CYP1A protein demonstrated maximal levels after $96 \mathrm{~h}$ of exposure
(Grosvik et al., 1997). As a reference tissue in the laboratory induction time-course, liver samples after 7 days of exposure showed $370 \times$ as much CYP1A mRNA in induced fish than control fish. This is similar to the induction levels observed in liver tissue after 2 days of exposure in Rees et al. (2003). Likewise, maximum induction of CYP1A estimated from gill tissues taken by destructive sampling from Atlantic salmon under virtually identical conditions (Rees et al., 2003) was very similar to the induction levels in the present study. This high level of similarity further confirms the accuracy of non-lethal sampling approaches to measure CYP1A levels.

Our analysis of CYP1A from salmon of Millers River and Fourmile Brook demonstrated that the gill biopsy Q-RTPCR approach is useful in measuring CYP1A activity in salmon from the wild. The elevated level of CYP1A in Millers River fish is similar to those seen previously using large quantities of gill tissue from destructive sampling (Rees et al., 2003). These elevated levels of CYP1A mRNA are likely due to induction by PCBs, known to be higher in Millers River (Colman, 2001) than in Fourmile Brook. Although temperature and other factors may affect CYP1A activity (Kloepper-Sams and Stegeman, 1992; Grosvik et 
al., 1997, Rees et al., 2003), temperature profiles in these streams were similar and sampling on the two rivers occurred within a short period of time during which the temperature varied less than $1{ }^{\circ} \mathrm{C}$.

Although this gill biopsy assay offers the possibility of developing non-lethal monitoring programs for toxicity testing, there are some important considerations to evaluate before sampling an endangered or threatened population of fish. Our wild salmon were sampled through stream backpack electro-shocking. We did not compare sampling techniques but saw no problems with using electro-shocking to sample Atlantic salmon. This may not be the case with alternative species. We also found that our gill biopsies caused minimal bleeding, mostly due to the care taken to sample only from the distal portion of gill filaments and to take only six partial filaments. However, this is still an invasive technique and should be managed in a way to minimize stress as much as possible. Some important criteria to consider would be the time of year when sampling is performed, species that is sampled, water temperatures, and gear used to capture wild fish. We recommend sampling at times when dissolved oxygen levels are highest (cooler temperatures), having a thorough sampling and anesthesia protocol outlined, using appropriate instruments to collect the biopsies, and a firm understanding of the life history of the species with which biopsies are to be taken.

This study extends the use of gill biopsies to direct assessment of gene expression, in addition to studies of proteins and enzymatic activities. In the past, gill biopsies have been used for many applications in monitoring fish health, particularly in the aquaculture industry (Montgomery-Brock et al., 2001). The effect of gill biopsies $(2 \times 3 \mathrm{~mm})$ has also been tested on age- 0 juvenile chinook salmon (Oncorhynchus tshawytscha) that had been implanted with radio tags, showing that salmon with both a radio tag and gill biopsy have no adverse health or survival effects compared to salmon with only radio tags (Martinelli-Liedke et al., 1999). The effects gill biopsies have on the health of Atlantic salmon have been studied as well. Specifically, it has been shown that juvenile Atlantic salmon receiving gill biopsy showed no differences in mortality, growth rate, and the ability to regulate plasma sodium when exposed to saltwater as salmon without biopsies (McCormick, 1993). Likewise, Siegler et al. (1996) observed no differences in mortality or growth rate (length and weight) between the biopsy group and the control group of smolting salmon. Gill biopsies have also been used to study the relationship between premigratory gill $\mathrm{Na}^{+} / \mathrm{K}^{+}$-ATPase activity and future migratory behaviour in wild brown trout (Nielsen et al., 2004). In this study, we extended the application of this non-lethal technique to measuring changes of gene expression induced by environmental contaminants. Generally, all of the studies above took larger amounts of gill tissue for biopsies compared to this study and did not engage in repeated sampling of the same individual fish over time. This study sampled the same fish four times repeatedly over the course of 7 days and used smaller amounts of gill tissue than any of the aforementioned experiments and fish that were of the same size or smaller than any of the previous studies. Therefore, the methods described in this study expand the utility of using gill biopsies to study genetic, physiological, and toxicological effects on fish populations.

Previous studies of CYP1A induction in teleosts relied on EROD (ethoxy resorufin- $O$-deethylase) activity or ELISA to measure the effects on CYP1A protein and Northern blotting or slot blotting to examine the kinetics of induction on CYP1A mRNA levels (Goksøyr and Husøy, 1998). The size of gill biopsies described here would be too small to carry out induction studies with any of the techniques described above due to the sensitivities associated with each of the methods. RT-PCR is at least 10 -fold more sensitive in detecting CYP1A induction over EROD activity or radioimmunoassay and at least 100 -fold more sensitive than Northern or slot blotting in measuring CYP1A RNA (Vanden Heuvel et al., 1994). This level of sensitivity offered by Q-RT-PCR enabled us to study gene expression in smaller amounts of biopsy tissues and revealed a major advantage over other methods from a monitoring standpoint. Because the primers and probes for this CYP1A assay have been developed and optimized, other labs could adopt the assay in a matter of days. Processing RNA is the most time-consuming process, but the labor cost is lessening each year as new instrumentation through core facilities becomes available to federal, state, and university research labs. As molecular approaches become readily accessible to a wider degree of research facilities, the advantages this assay provides will become more apparent.

Gill biopsies have rarely been used to assay levels of gene expression in fish populations. We have determined in this study that non-lethal gill biopsies of Atlantic salmon coupled with Q-RT-PCR offer a conservation-based approach to studying gene expression in fish populations. Our specific assay may be useful in studying CYP1A levels in most salmonid species due to the high level of conservation of CYP1A genes in many fish species. In theory, quantitative PCR has the adaptability to study virtually any gene in any tissue of any fish species. With modifications in primer sequences and internal standards, the levels of any known gene can be analysed. It will be even more useful in a few years when the genomic data for several teleost species become readily available due to the many genome projects that are currently under way. The methods described in this paper will allow for repeated sampling of gill tissue from individual fish to study gene expression over time. This characteristic alone will lower the number of samples needed for studying gene expression in fish as well as offer an accurate and sensitive method in related time-course experiments. As more and more species are added to the endangered species list, this technique gives 
researchers and managers the needed flexibility to study physiological and genetic changes in threatened and possibly endangered fish populations without lowering an already small population.

\section{Acknowledgements}

Appreciation is extended to Amy Moeckel, Mike O'Dea, Darren Lerner and Junya Hiroi who helped in collecting Atlantic salmon gill biopsy samples and to Hong $\mathrm{Wu}$ for assisting in the extraction of RNA. Dr. Kim Scribner offered the use of gel imaging and electrophoresis equipment. Dr. Bradley Young offered advice and suggestions for statistical analysis. This research was funded by the National Oceanic Atmospheric Administration and by the Great Lakes Fishery Commission.

\section{References}

Arukwe, A., Yadetie, F., Male, R., Goksøyr, A., 2001. In vivo modulation of nonylphenol-induced zonagenesis and vitellogenesis by the anti-

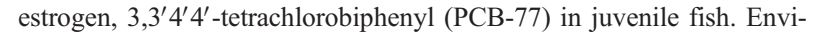
ron. Toxicol. Pharmacol. 10, 5-15.

Bakke, T.A., Harris, P.D., 1998. Diseases and parasites in wild Atlantic salmon (Salmo salar) populations. Can. J. Fish. Aquat. Sci. 55 (Suppl. 1), 247-266.

Billiard, S.M., Bols, N.C., Hodson, P.V., 2004. In vitro and in vivo comparisons of fish-specific CYP1A induction relative potency factors for selected polycyclic aromatic hydrocarbons. Ecotoxicol. Environ. Saf. 59, 292-299.

Campbell, P.M., Devlin, R.H., 1996. Expression of CYP1A1 in livers and gonads of Pacific salmon: quantitation of mRNA levels by RT-cPCR. Aquat. Toxicol. 34, 47-69.

Colman, J.A., 2001. Source identification and fish exposure for polychlorinated biphenyls using congener analysis from passive water sampler in the Millers River Basin, Massachusetts. USGS Water-Resour. Invest. Rep. 00-4250.

Committee on the Status of Endangered Wildlife in Canada, 2002. Canadian Species at Risk, pp. 1-39. May.

Cousinou, M., Nilsen, B., Lopez-Barea, J., Dorado, G., 2000. New methods to use fish cytochrome P4501A to assess marine organic pollutants. Sci. Total Environ. 247, 213-225.

Elson, P.F., 1967. Effects on wild young salmon of spraying DDT over new Brunswick forests. J. Fish. Res. Board Can. 24, 731-767.

Fairchild, W.L., Swansburg, E.O., Arsenault, J.T., Brown, S.B., 1999. Does an association between pesticide use and subsequent declines in catch of Atlantic salmon (Salmo salar) represent a case of endocrine disruption? Environ. Health Perspect. 107, 349-358.

Goksøyr, A., Husøy, A.M., 1998. Immunochemical approaches to studies of CYP1A localization and induction by xenobiotics in fish. Fish Ecotoxicol. 86, 165-202.

Grosvik, B., Larsen, H., Goksøyr, A., 1997. Effects of piperonyl butoxide and beta-naphthoflavone on cytochrome P4501A expression and activity in Atlantic salmon (Salmo salar L). Environ. Toxicol. Chem. $16,415-423$.

Hahn, M.E., Stegeman, J.J., 1994. Regulation of cytochrome P450 1A1 in teleosts: sustained induction of CYP1A1 messenger-RNA, protein, and catalytic activity by 2,3,7,8 tetrachlorodibenzofuran in the marine fish Stenotomus chrysops. Toxicol. Appl. Pharmacol. 127, 187-198.

Jones, S.B., King, L.B., Sappington, L.C., Dwyer, F.J., Ellersieck, M., Buckler, D.R., 1998. Effects of carbaryl, permethrin, 4-nonylphenol, and copper on muscarinic cholinergic receptors in brain of surrogate and listed fish species. Comp. Biochem. Physiol. C 120, 405-414.

Jonsson, M.E., Brunstrom, B., Ingebrigtsen, K., Brandt, I., 2004. Cellspecific CYP1A expression and benzo[a]pyrene adduct formation in gills of rainbow trout (Oncorhynchus mykiss) following CYP1A induction in the laboratory and in the field. Environ. Toxicol. Chem. 23, 874-882.

Kloepper-Sams, P.J., Stegeman, J.J., 1992. Effects of temperature acclimation on the expression of hepatic cytochrome P4501A mRNA and protein in the fish Fundulus heteroclitus. Arch. Biochem. Biophys. 299, $38-46$.

MacCrimmon, H.R., Gots, B.L., 1979. World distribution of Atlantic salmon, Salmo salar. J. Fish. Res. Board Can. 36, 422-457.

Martinelli-Liedke, T.L., Shively, R.S., Holmberg, G.S., Sheer, M.B., Schrock, R.M., 1999. Nonlethal gill biopsy does not affect juvenile chinook salmon implanted with radio transmitters. N. Am. J. Fish. Manage. 19, 856-859.

McCormick, S.D., 1993. Methods for nonlethal gill biopsy and measurement of $\mathrm{Na}^{+} \mathrm{K}^{+}-$ATPase activity. Can. J. Fish. Aquat. Sci. $50,656-658$.

McMaster, M.E., 2001. A review of the evidence for endocrine disruption in Canadian aquatic ecosystems. Water Qual. Res. J. Can. 36, 215-231.

Miller, H., Bembo, D.G., Macdonald, J.A., Evans, C.W., 1999. Induction of cytochrome P4501A (CYP1A) in Trematomus bernacchii as an indicator of environmental pollution in Antarctica: assessment by quantitative RT-PCR. Aquat. Toxicol. 44, 183-193.

Montgomery-Brock, D., Sato, V.T., Brock, J.A., Tamaru, C.S., 2001. The application of hydrogen peroxide as a treatment for the ectoparasite Amyloodinium ocellatum (Brown 1931) on the Pacific threadfin Polydactylus sexfilis. J. World Aquac. Soc. 32, 250-254.

Moore, A., Waring, C.P., 1998. Mechanistic effects of a triazine pesticide on reproductive endocrine function in mature male Atlantic salmon (Salmo salar L.) parr. Pestic. Biochem. Physiol. 62, 41-50.

Moore, A., Waring, C.P., 2000. The effects of a synthetic pyrethoid pesticide on some aspects of reproduction in Atlantic salmon (Salmo salar L.). Aquat. Toxicol. 52, 1-12.

Moore, A., Scott, A.P., Lower, N., Katsiadaki, I., Greenwood, L., 2003. The effects of 4-nonylphenol and atrazine on Atlantic salmon (Salmo salar L.) smolts. Aquaculture 222, 253-263.

Navas, J., Segner, H., 2001. Estrogen-mediated suppression of cytochrome P450 1A (CYP1A) expression in rainbow trout hepatocytes: role of estrogen receptor. Chem.-Biol. Interact. 138, 285-298.

Nielsen, C., Aarestrup, K., Norum, U., Madsen, S.S., 2004. Future migratory behavior predicted from premigratory levels of gill $\mathrm{Na}+/ \mathrm{K}(+)$-ATPase activity in individual wild brown trout (Salmo trutta). J. Exp. Biol. 207, 527-533.

Ortiz-Delgado, J.B., Sarasquete, C., 2004. Toxicity, histopathological alterations and immunohistochemical CYP1A induction in the early life stages of the seabream, Sparus aurata, following waterborne exposure to B(a)P and TCDD. J. Mol. Histol. 35, 29-45.

Parrish, D.L., Behnke, R.J., Gephard, S.R., McCormick, S.D., Reeves, G.H., 1998. Why aren't there more Atlantic salmon (Salmo salar)? Can. J. Fish. Aquat. Sci. 55 (Suppl. 1), 281-287.

Rees, C.B., McCormick, S.D., Vanden Heuvel, J.P., Li, W., 2003. Quantitative PCR analysis of CYP1A induction in Atlantic salmon (Salmo salar). Aquat. Toxicol. 62, 67-78.

Sambrook, J., Fritsch, E.F., Maniatas, T., 1989. Molecular Cloning: a Laboratory Manual, 2nd edition. Cold Spring Harbor Laboratory Press, New York.

Sarasquete, C., Segner, H., 2000. Cytochrome P4501A (CYP1A) in teleostean fishes. A review of immunohistochemical studies. Sci. Total Environ. 247, 313-332.

Siegler, L., D'Cotta, H., Paulin, L., Bagliniere, J.L., Prunet, P., 1996. Biopsy and measurement of branchial $\mathrm{Na}^{+} / \mathrm{K}^{+}$ATPase activity: validity and impact on Atlantic salmon (Salmo salar) smolt development. B. Fr. Peche Piscic. 340, 43-55. 
U.S. Department of Interior, 2000. Endangered and Threatened Species; Final Endangered Status for a Distinct Population Segment of Anadromous Atlantic Salmon (Salmo salar) in the Gulf of Maine, Federal Register, vol. 65, pp. 69459-69483.

Vanden Heuvel, J.P., 1998. PCR Protocols in Molecular Toxicology. CRC Press, New York, pp. 41-99.

Vanden Heuvel, J.P., Clark, G.C., Kohn, M.C., Tritscher, A.M., Greenlee, W.F., Lucier, G.W., Bell, D.A., 1994. Dioxin-responsive genes: examination of dose-response relationships using quantitative reverse transcriptase-polymerase chain reaction. Cancer Res. 54, $62-68$.

Youngson, A.F., Verspoor, E., 1998. Interactions between wild and introduced Atlantic salmon (Salmo salar). Can. J. Fish. Aquat. Sci. 55 (Suppl. 1), 153-160. 